\title{
EFFECTS OF HUMAN IMPACT ON THE BEDS OF MINOR WATERCOURSES OF THE AEGEAN ISLAND OF ICARIA (GREECE)
}

\author{
IRENA TSERMEGAS \\ University of Warsaw, Institute of Physical Geography, Warsaw, Poland
}

Manuscript received: June 10, 2011

Revised version: March 9, 2012

\begin{abstract}
TSERMEGAS I., Effects of human impact on the beds of minor watercourses of the Aegean Island of Icaria (Greece). Quaestiones Geographicae 31(1), Bogucki Wydawnictwo Naukowe, Poznań 2012, pp. 91-98. 8 Figs. DOI 10.2478/ v10117-012-0007-7, ISSN 0137-477X.
\end{abstract}

AвSTRACT. The aim of the work was to show the scale of changes of riverbeds in the conditions of Mediterranean climate and many ages of human impact, on the example of Icaria, an island situated in the eastern part of the Aegean Sea. The most altered riverbed fragments were selected and the main types of conversion were defined based on the terrain mapping and the interviews with the inhabitants. They are as follows: the increase in the seasonality of tides, the transformation of the riverbed fragments into paths, the narrowing of the riverbeds, the strengthening of their bottoms and banks, the partitioning of the riverbeds with the proprietary boundaries, the inclusion of the riverbeds into the irrigation system and the creation of infrastructure to be used by watermills. The riverbeds that were altered the most were the ones within villages, up to $400 \mathrm{~m}$ above sea level.

Changes described were taking place in stages. In antiquity they concerned only the estuary parts. Until the 1950s they covered arable areas inside the island. After 1970 there followed a drastic diminishing of flows in the riverbeds and there appeared riverbeds with artificial bottoms.

KEY WORDS: Icaria, river bed, human impact

Irena Tsermegas, Institute of Physical Geography, University of Warsaw, ul. Krakowskie Przedmieście 30, 00-927 Warsaw, Poland, e-mail: argiro@uw.edu.pl

\section{Introduction}

There exists a great number of works concerned with the human impact on the functioning of fluvial systems in the Mediterranean area. This problem had already been noticed in the classical works on the river valleys of the described climatic zone (Vita-Finzi 1969). The most frequently considered aspects of human impact are the effects of: changes in the land use (especially the ef- fects of deforestation, fires and cessation of land farming), terracing slopes in drainage basins, the building of dams and irrigation systems and urbanization. Usually it is greatly emphasized that among all the microclimatic zones it is the Mediterranean area that is characterized by the biggest role of the human in the last several thousand years in the transformation of drainage basins and riverbeds (Hooke 2006). The increase in the occurrence and spatial extent of disastrous phe- 
nomena, floods mainly, is commonly considered the most important effect of those changes (Sala 2003).

The concept of human influence on the fluvial system of relatively small islands of the Aegean Sea has been somewhat the least known. This problem concerns especially forms connected with the agricultural economy that have been transformed or created in the last couple of centuries. This work follows the afore mentioned research trend. Its aim is to show the scale of anthropogenic transformations of riverbeds functioning in Mediterranean climate and remaining periodically under human influence for at least 2500 years. The presented conclusions are the result of research of the fragments of riverbeds selected on the basis of mapping of contemporary morphogenetic processes on Icaria previously done by the author (Tsermegas 2007). Available topographic maps were used in order to compare the current condition of the researched system with its condition about 50 years ago. Outdoor interviews were also run in order to confirm the suppositions concerning the fact that local population calls many periodical streams "rivers"

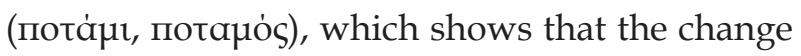
in their character has taken place relatively recently.

\section{Scope of research}

Icaria is a mountainous island with an area of $255 \mathrm{~km}^{2}$ situated in the eastern part of the Aegean Sea. In its structure there prevail crystalline rocks (granitoids gneiss, crystalline schist and marble). The main axis of Icaria is constituted by a 40-kilometre mountain range which goes from WSW to ENE dividing the island into the southern part (steep) and the northern one (with a much lower gradient but more fragmented).

Culminations in many places exceed $800 \mathrm{~m}$ above sea level. The highest peak reaches 1,042 m above sea level. The area is cut by a dense network of valleys (up to $5 \mathrm{~km} / \mathrm{km}^{2}$ ) drained mainly by periodic and episodic watercourses. The length of most of them does not exceed $3 \mathrm{~km}$. Currently only two streams have water during the whole year on the section longer than $2 \mathrm{~km}$. Average gradients of the riverbeds in the southern part

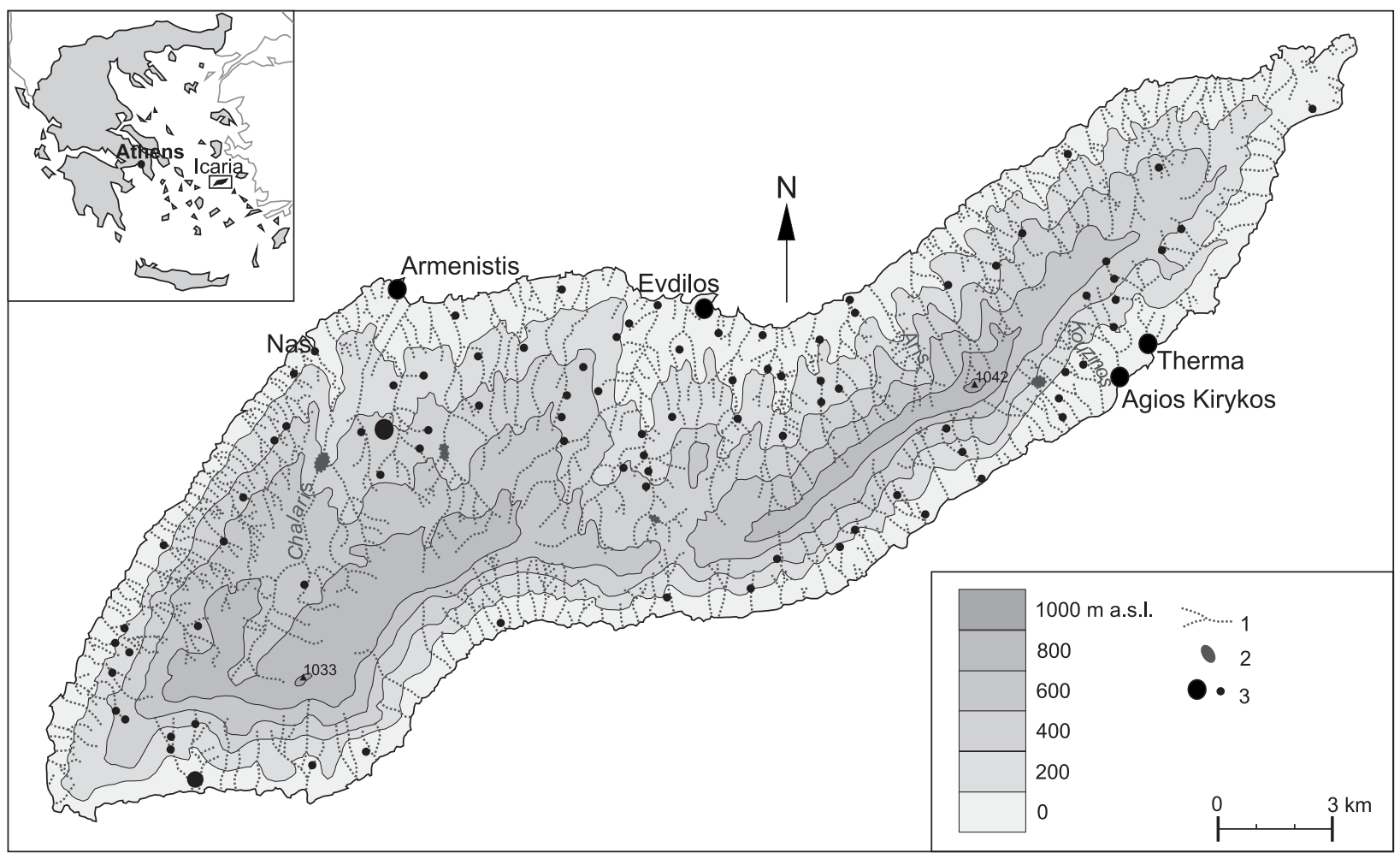

Fig. 1. Hypsometric sketch and the spatial distribution of settlements on Icaria. 1 - hydrographic network, 2 - artificial water reservoirs, 3 - villages. 


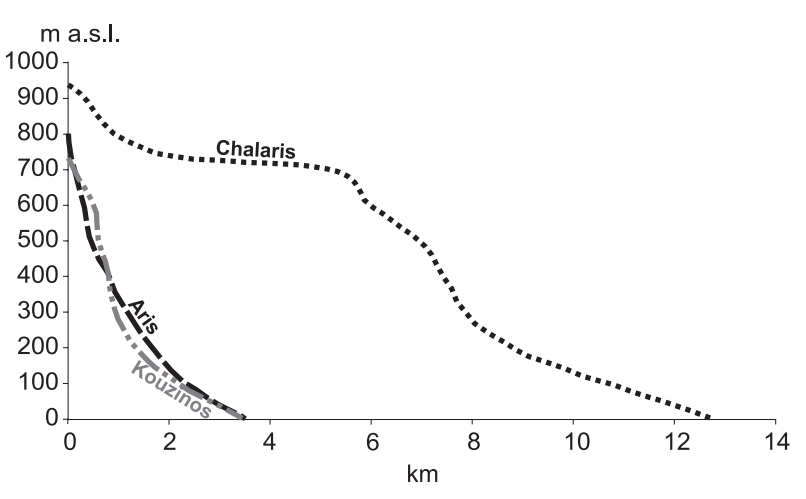

Fig. 2. Longitudinal profiles of selected riverbeds.

of the island reach approximately $200 \%$, in the north they are lower, but in all the cases they exceed 50\% (Fig. 1 and 2).

There are over 50 minor settlements on the island, 3 of which have an official municipal status. However, in none of them dense development takes more than $1 \mathrm{~km}^{2}$. All settlements are located in the valleys (Fig. 1). Their functioning would not be possible without the access to sweet water, the sufficiently efficient sources of which are found solely along the streambeds. In summer months precipitation is low enough not to provide conditions sufficient to fulfill the needs of the population (Fig. 3).

The history of settlement on Icaria reaches at least IV millennium B.C. In VIII century B.C. first cities was founded there (Papalas 1992). They were located in the lower parts of large river valleys. In VI century B.C. the port of Tavropolion was built in the NW island coast at the mouth of one of the longest streams with the largest water supply (Fig. 1). It was the first investment in Icaria, which was connected with the deepening, widening and strengthening of the riverbed. The traces of those actions are visible until today (Fig. 4).

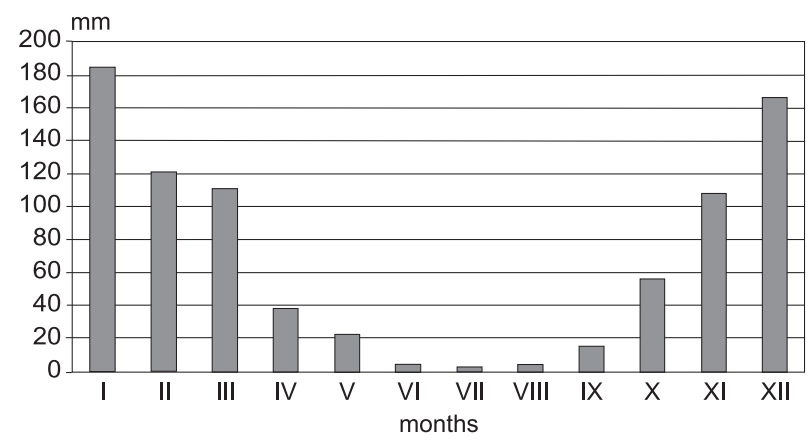

Fig. 3. Average monthly sums of precipitation on the Agios Kirykos station in 1932-1986 (according to the data of National Meteorological Service - EMY).

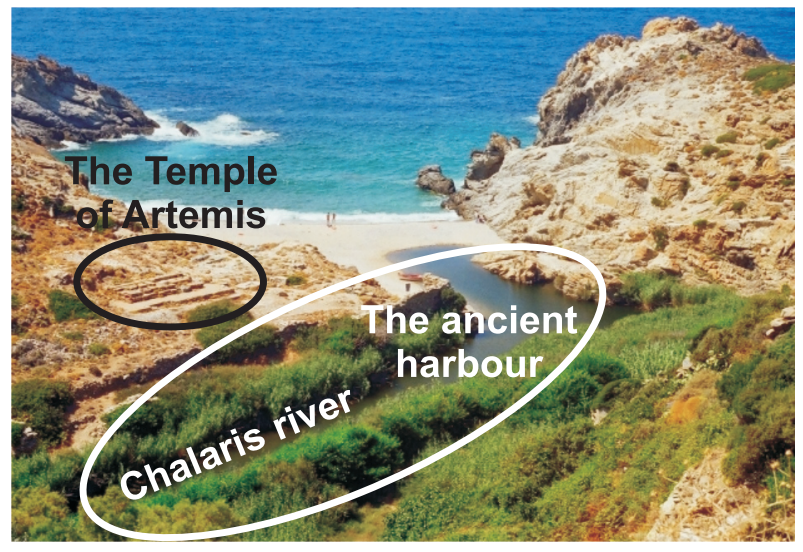

Fig. 4. The oldest port of Icaria - artificially deepened and strengthened mouth of the stream of Chalaris in the village of Nas (ancient Tavropolion).

\section{Demonstrations of human impact}

The research done let distinguish several types of transformations registered in the riverbeds of streams of Icaria. The most important of them are as follows:

- the change of some stable riverbeds into periodic ones,

- the transformation of riverbed fragments into paths,

- the narrowing of riverbeds in the area of villages and in vicinity of roads,

- the strengthening of riverbed bottoms and banks in the majority of larger villages,

- the partitioning of the riverbeds with proprietary boundaries,

- the inclusion of riverbeds into the irrigation system,

- the creation of infrastructure for the needs of watermills.

The first of above mentioned effects of human impact is mainly the result of the large increase in the water usage by the inhabitants of the island. The construction of waterway and sewage system on Icaria was started as late as after II WW. The largest number of water intakes was built in the last quarter of $\mathrm{XX}$ century. Water is taken directly from the sources and it practically does not return to the area of the drainage basin it was taken from. Thus during dry periods most riverbeds are deprived of stable flow. Earlier the influence of settlements on the streambeds was mainly connected with the construction of not large reservoirs used for watering fields. Most of those 


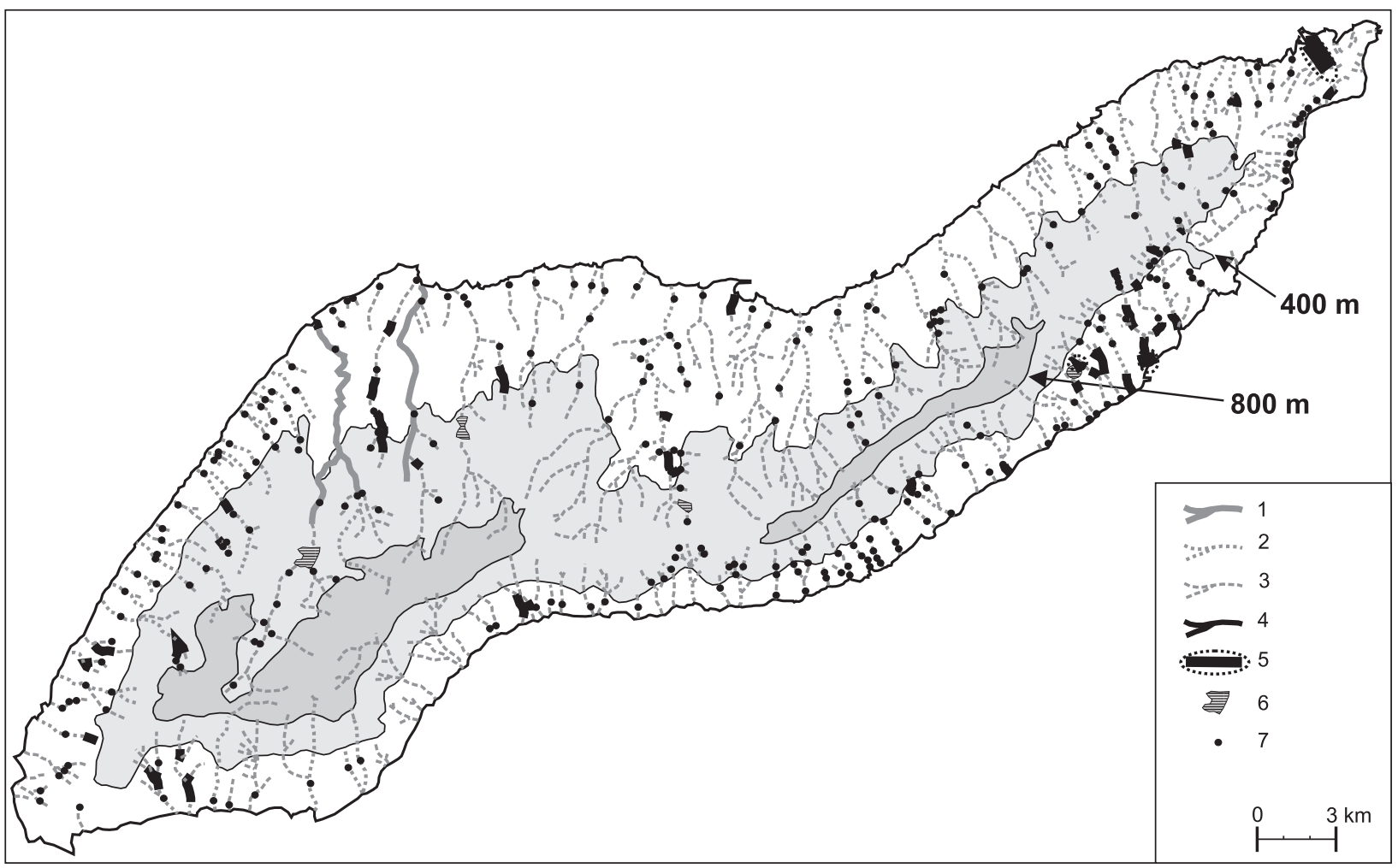

Fig. 5. Anthropogenic transformation of riverbeds in Icaria.

1 - stable riverbeds, 2 - riverbeds that used to be stable and currently are periodic, 3 - other periodic and episodic riverbeds, 4 - narrowed riverbeds, 5 - concreted riverbeds (including the covered one), 6 - artificial water reservoirs, 7 - sluices.

structures functioned for centuries and they have been preserved until today. However, only some of them are still used - they were converted into water intakes and included in the country waterway system. A similar role was played by deep wells. The first ones were drilled in the 1980s. The most efficient ones deliver up to $600 \mathrm{~m}^{3}$ of water a day in the dry season.

The conclusion from the interviews done with the local population is that in the second half of XX c. at least 30 stable streams were transformed into the periodic waterways. Currently only two waterways on the island have water all year round. Both of them drain the area constructed from granite gneiss. The zone of their supply is an extensive plateau Pezi - the only part of Icaria where the slopes have a relatively low gradient. In this area there are also the largest forest terrains (Fig. 5).

Direct transformations of riverbeds of Icaria are connected with the fact that in the dry periods those lines have been commonly used as paths. It concerns especially the fragments located within villages. Therefore, in many places the bottom of riverbeds is leveled and enforced, artificially deprived of the thick lining material.

A common phenomenon on the island is also the regulation of riverbeds running along the communication trails. Initially it concerned only the urban areas. However, the introduction of vehicular traffic (the 1950s) broadened the extent of regulation to the areas directly located by asphalt roads. Most of all the riverbeds that cross those roads were significantly narrowed (construction of sluices) (Fig. 6a).

The largest transformations took place within the main settlements, located in the lower parts of major river valleys. In the capital of the island (Agios Kirykos) the riverbed was concreted and totally covered on the section of $200 \mathrm{~m}$ (up to the mouth). In the nearby health resort of Therma the whole section of the riverbed running through the town was changed into a car park with an additional role of a road (Fig. 6b).

The specific character of the Aegean landscape is that the proprietary boundaries take there most commonly a form of permanent stone constructions - walls of different height and width. Some 

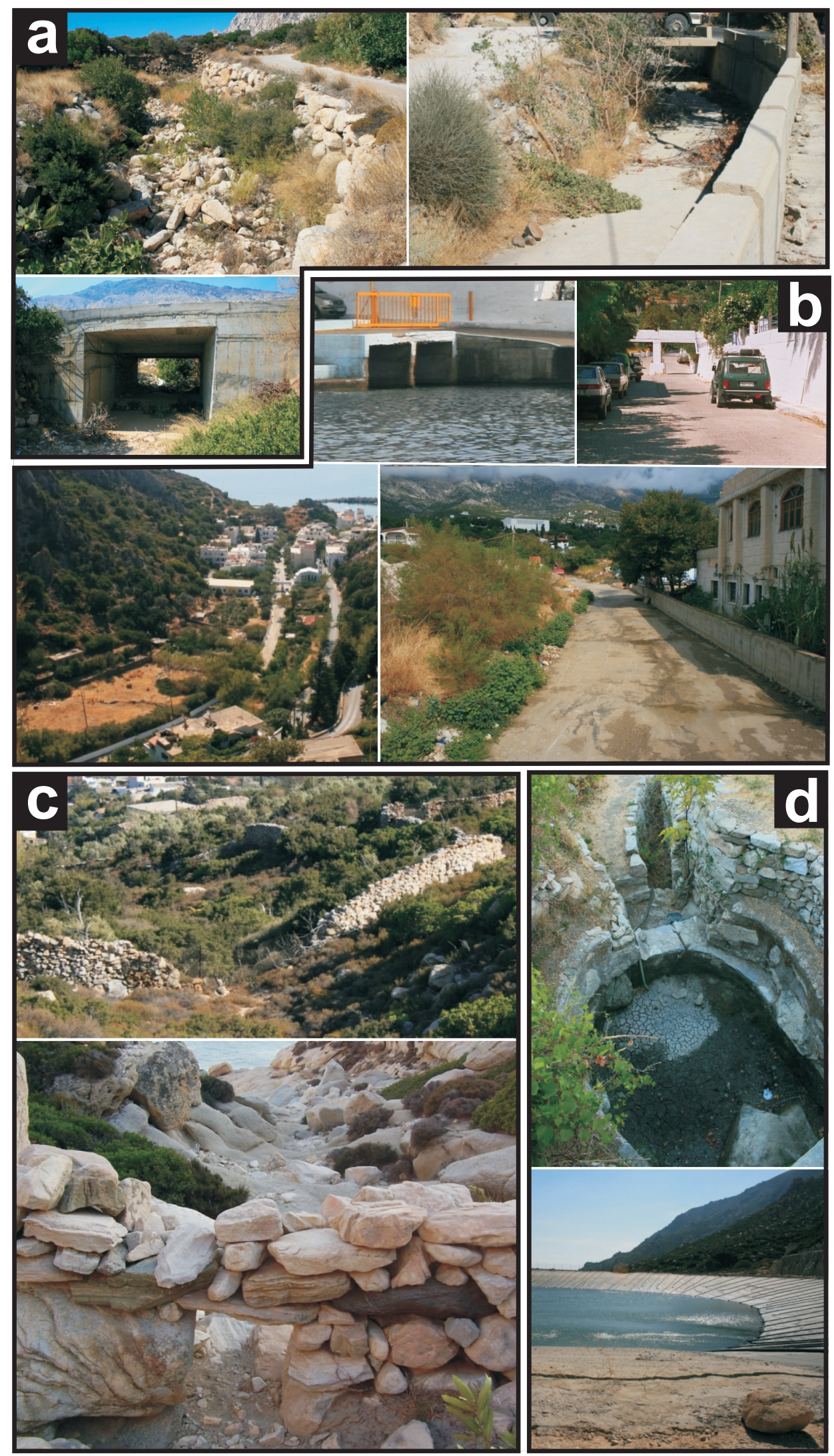

Fig. 6. Effects of various demonstrations of human impact in riverbeds of Icaria

$\mathrm{a}$ - examples of regulated and narrowed riverbed running along or across roads, $\mathrm{b}$ - transformations of riverbeds in cities, $\mathrm{c}$ - proprietary boundaries led across valleys and riverbeds, $\mathrm{d}$ - riverbeds as a part of irrigation system. 
of them cross riverbeds making them more narrow locally (Fig. 6c). This process, however, is becoming insignificant because older boundaries are seldom rebuilt after being destroyed by water.

All the ancient settlements on Icaria developed near the low situated valley parts, the bottoms of which could be easily adjusted for agricultural purposes. Water for the fields was taken directly from streams and it was supplied all year round (Fig. 5). The later increase of population together with the breakdown of Greek marine power as well as the fact that the seas around Icaria became controlled by pirates made it necessary to develop the areas located in the centre of the island and abandon the shores (Melas 1955). Farming on the mountain slopes required the creation of a system of terraces and the provision of the possibility of watering in the summer. For that purpose riverbeds were partitioned and in every village at least one irrigation reservoir was created (usually directly below a source with stable efficiency), from which water was run through canals to all the allotments. In the dry season the riverbed below the reservoir remained dry in a large part. Most of the reservoirs have been functioning until today, although only a few have remained. The other ones were covered with sludge or they were rebuilt, covered and included in the waterway system (Fig. 6d).

In the second half of the XX century big artificial water reservoirs started to be created on Icaria. Currently three of them are operational - two dam ones (Agios Polikarpos and Pezi) and one with a totally artificial bowl (above the village of Glaredo). Their total capacity is approximately 1 million $\mathrm{m}^{3}$.

Among other effects of human impact on the riverbeds of the island the ones worth mentioning are constructions backing up water, small reservoirs and canals leading water for the needs of several watermills that were functioning until the 1950s. Such constructions are especially common in the eastern part of the island, where due to large disparity between the terrain levels, even a relatively small amount of water was enough to obtain energy sufficient to move the mechanism of the mill. During the time of work of the mill the fragment of riverbed above it remained dry or deprived of a significant portion of water that would flow in it in natural conditions. Below the mill the water powering it returned to the riverbed and it could be used repeatedly. Therefore, it is possible for two mills to exist on different levels along one stream locally (Fig. 7).

\section{Conclusions}

Centuries of human management on Icaria contributed to large direct changes of riverbeds. The riverbeds within the area of villages, on the sections below $400 \mathrm{~m}$ above sea level were changed the most. On the terrains with dense development there operate solely regulated and artificially enforced riverbeds. Beyond $800 \mathrm{~m}$ above sea level riverbeds have retained their natural character almost completely.

Moreover, human impact (intake of water) has caused a significant decrease of flow in waterways of Icaria. There is a lack of precise data concerning the usage of water in households on Icaria. On the basis of information from literature concerned with the Aegean region (Avlonitis et al. 2003) it might be assumed that it reaches not less than $50 \mathrm{~m}^{3}$ per inhabitant, which means in case of Icaria approximately 500,000 $\mathrm{m}^{3} /$ year. It should also be taken into consideration that in the dry summer season at least twice as many people visit the island than in winter and tourists use up much more water on a daily basis than the permanent residents of Icaria. Therefore since the moment of the construction of the first water intakes in the second half of the XX c. over $90 \%$ of permanent waterways became transformed into periodic ones. The phenomenon did not concern only two streams in the northern part of the island, which drain a large forest area. It points clearly to a anthropogenic and not climatic cause of the observed changes.

The transformations of Icarian riverbeds connected with human activity always took place in stages:

- In the ancient times changes concerned only the lower sections.

- From the beginning of XVI c. to the middle of $X X$ c. they encompassed agricultural areas inside the island (narrowing the riverbeds, the creation of irrigation system, mills); seasonality of flow changed only due to natural conditions. 


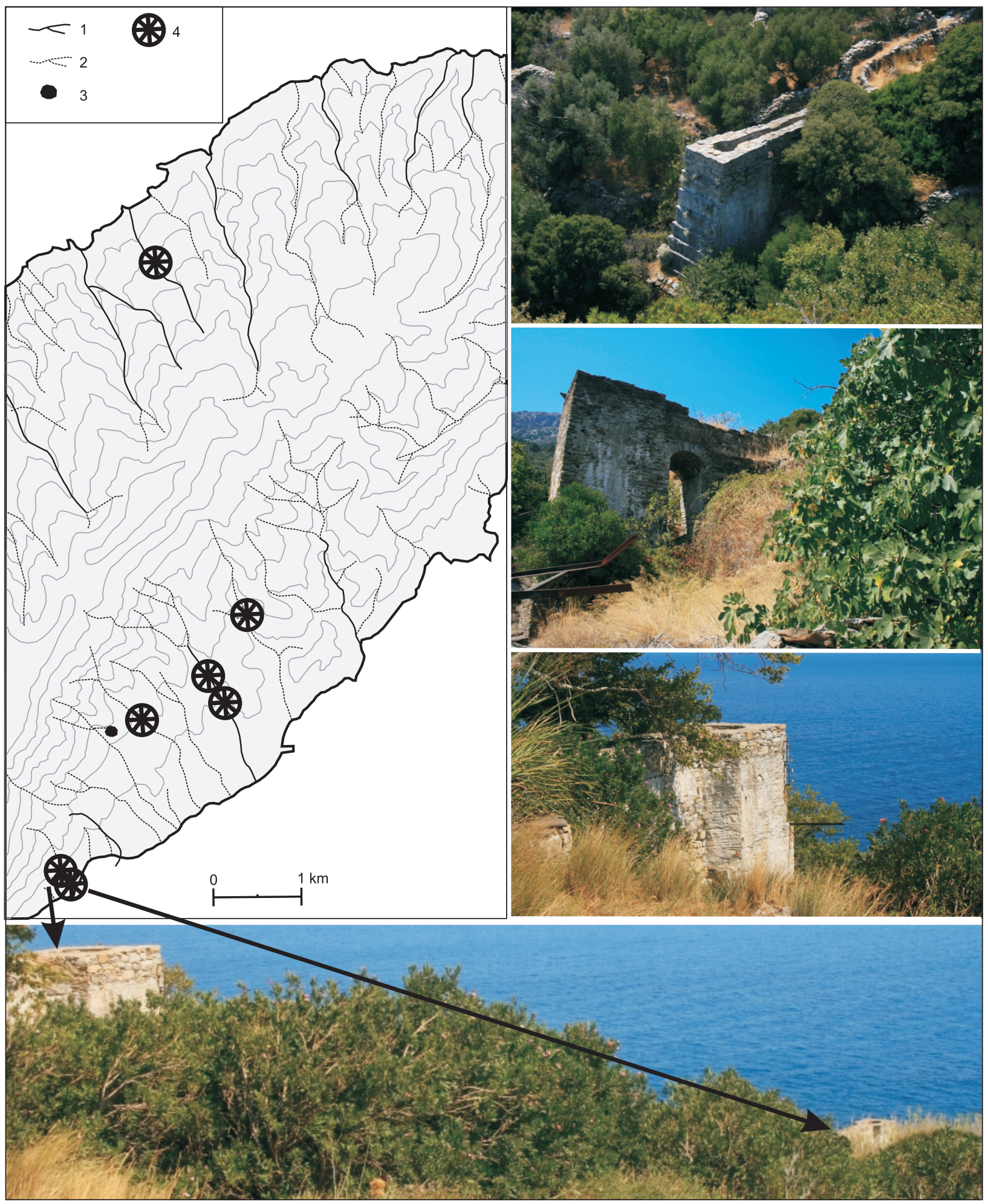

Fig. 7. Remnants of watermills in the eastern part of Icaria.

1 - riverbeds that used to be stable and currently are periodic, 2 - other periodic and episodic riverbeds, 3 - artificial water reservoirs, 4 water mills. 
- After 1970 due to the creation of waterway and sewage system there took place a drastic decrease of flow in the riverbeds; riverbeds with artificial bottoms appeared.

Such major transformations of the river network do not remain without significance for the course of current riverbed processes on the island. The most important consequence of the decrease of flows is the loss of material from the beaches supplied mostly by streams. On the other hand, during intensive winter rainfall (up to several dozens $\mathrm{mm}$ in 24 hours) roads become covered with sludge or washed away due to too narrow sluices. The introduction of urban development on the areas neighbouring the narrowed and partly covered mouth riverbed fragments results in local floods causing significant material losses - last such case took place in the capital of the island at the beginning of 2006.

\section{References}

Avlonitis S.A., Poulios I., Vlachakis N., Tsitmidelis S., Kouroumbas K., Avlonitis D., Pavlou M., 2003. Water resources management for the prefecture of Dodekanisa of Greece. Desalination, 152: 41-50.

HooKe J.M., 2006. Human impacts on fluvial systems in the Mediterranean region. Geomorphology, 79: 311-335.

Melas I., 1955. Iotopia $\tau \eta$ ऽ víoov Ikapias (History of the Icaria Island; in Greek), vol. 1. Athens.

Papalas A.J., 1992. Ancient Icaria. Bolhazy-Carducci Publ., Wauconda. 1-215.

SALA M., 2003. Floods triggered by natural conditions and by human activities in a Mediterranean coastal environment. Geografiska Annaler, 85A (3-4): 301-312.

TSERMEGAS I., 2007. Znaczenie procesów naturalnych i antropogenicznych dla współczesnych przemian rzeźby Ikarii. In: Tsermegas I. (ed.), Warsztaty Geomorfologiczne „Naturalne $i$ antropogeniczne procesy rzeźbotwórcze w warunkach śródziemnomorskich", Grecja, 26.04-06.05.2007, WGiSR UW, SGP, NUA, Warszawa: 52-63.

Vita-Finzi C., 1969. The Mediterranean Valleys. Cambridge University Press, Cambridge. 